\title{
Nitric Oxide Delays the Death of Trophic Factor-Deprived PC12 Cells and Sympathetic Neurons by a cGMP-Mediated Mechanism
}

\author{
Stephen E. Farinelli, David S. Park, and Lloyd A. Greene \\ Department of Pathology and Center for Neurobiology and Behavior, Columbia University College of Physicians and \\ Surgeons, New York, New York 10032
}

\begin{abstract}
We have used cultured $\mathrm{PC} 12$ cells and rat sympathetic neurons as model systems to examine the regulation of neuronal cell death and survival. Because nitric oxide (NO) may be involved in nerve growth factor (NGF) signaling in PC12 cells, we tested NO-generating compounds for their ability to protect $\mathrm{PC} 12$ cells and sympathetic neurons from death after withdrawal of trophic support. Three such agents, S-nitroso- $\mathrm{N}$ acetylpenicillamine (SNAP), diethylenetriamine NO adduct (DETA-NO), and sodium nitroprusside provide (SNP), were found to promote complete short-term survival after removal of serum from naive PC12 cells and of NGF from neuronally differentiated PC12 cells and sympathetic neurons. One major target of NO action is guanylate cyclase, which is activated by nitrosylation of its heme prosthetic group. We observed that
\end{abstract}

Much recent evidence implicates nitric oxide (NO) as a major synaptic signaling agent in the nervous system (Bredt and Snyder, 1992; Snyder, 1992). Apart from this role under physiological conditions, NO appears to mediate neuronal death when produced in excess. For instance, during cerebral ischemia, excessive glutamate release leads to overstimulation of NMDA receptors which in turn causes $\mathrm{Ca}^{2+}$ influx and activation of the $\mathrm{Ca}^{2+}$ dependent form of NO synthase (NOS) (Garthwaite, 1991). Because inhibitors of NOS reduce the extent of brain damage caused by experimentally induced cerebral ischemia, $\mathrm{NO}$ appears to be intimately involved in the death process (Nowicki et al., 1991). This is further supported by observations that NOS inhibitors as well as other agents that reduce NO levels protect cultured neurons from glutamate toxicity (Dawson et al., 1991, 1993). The mechanism by which excessive NO leads to neuronal cell death is unclear but could include direct activation or inhibition of signaling or metabolic pathways (Stamler, 1994; Zhang et al., 1994) or reaction with superoxide to form the highly reactive peroxynitrite anion (Beckman et al., 1990; Lipton, 1993; Estevez et al., 1995; Mitrovec et al., 1995; Troy et al., 1996).

NO has also been reported to be cytoprotective in certain circumstances. For instance, NO donors and the NO precursor,

\footnotetext{
Received Nov. 10, 1995; revised Jan. 11, 1996; accepted Jan. 16, 1996.

This work was supported in part by grants from National Institutes of HealthNational Institute of Neurological Diseases and Stroke (NIH-NINDS) and March of Dimes Birth Defects Foundalion. S.F.F. was supported in part by a postfoctoral training grant from the National Cancer Institute (5 T32 CA09503) and a National Research Service Award from NIH-NINDS (1 F32 NS09639). D.P. was supported in part by a postdoctoral training grant from the National Institute of Mental Health (MH15174-18). We thank Dr. C. Troy for helpful discussion.

Correspondence should be addressed to Lloyd A. Greene, Department of Pathology and Center for Neurobiology and Bchavior, Columbia University College of Physicians and Surgeons, 630 West 168th Street, New York, NY 10032.

Copyright 1996 Society for Neuroscience $0270-6474 / 96 / 162325-10 \$ 05.00 / 0$
}

inhibition of guanylate cyclase blocks the protective effects of the NO generators on trophic factor-deprived PC12 cells and sympathetic neurons without preventing NGF-induced survival. We also found that permeant CGMP analogs and an inhibitor of cGMP-specific phosphodiesterase enhance cell survival, suggesting that the protective effects of NO are mediated by activation of guanylate cyclase and increased intracellular cGMP. N-Nitro-L-arginine methyl ester, a NO synthase inhibitor, did not block NGF-promoted PC12 cell or sympathetic neuron survival. These findings indicate that like NGF, NO has survivalpromoting actions on neurons but that the two agents work by initially independent mechanisms.

Key words: guanylate cyclase; apoptosis; nitric oxide; CGMP; PC12, sympathetic neurons; neuronal death

L-argininc, are cardioprotective in models of myocardial ischemia-reperfusion (Johnson et al., 1991; Morikawa et al., 1992; Siegfried et al., 1992). Very recent studies have revealed that NO inhibits apoptosis of human B lymphocytes caused by EpsteinBarr virus reactivation (Mannick et al., 1994) and antigen presentation (Genaro et al., 1995) as wcll as the death of cytokincdeprived human eosinophils (Beauvais et al., 1995).

The effects of NO with regard to cytoprotection have led us to examine its actions on several well characterized neuronal models in which cell death is initiated by withdrawal of trophic support. One of these consists of primary cultures of rodent sympathetic neurons, which are dependent on nerve growth factor (NGF) for support and which undergo apoptotic death after NGF withdrawal (Edwards et al., 1991; Batistatou and Greene, 1993). The other system is represented by the $\mathrm{PCl} 2$ rat pheochromocytoma cell line. In serumcontaining medium, $\mathrm{PC} 12$ cells replicate and display many characteristics of pheochromoblasts, the precursors of chromaffin cells and sympathetic neurons (Greene and Tischler, 1976). Within several days of exposure to NGF, these cells stop dividing and undergo neuronal differentiation. When cultured in serum-free medium without NGF or other growth factors, both pheochromoblast-like and neuronally differentiated (NGF-pretreated) PC12 cells die by an apoptotic mechanism. However, addition of NGF to the serum-free medium rescues the cells from death. Thus, in serum-free conditions, PC12 cells resemble sympathetic neurons in the requirement for NGF (Greene, 1978; Batistatou and Greene, 1991; Rukenstein et al., 1991).

We and others have proposed that withdrawal of trophic support causes neuronal cells to die because they inappropriately attempt either to traverse the cell cycle (if in a proliferative stage) or (if postmitotic) to reenter the cell cycle (Batistatou and Greene, 1993; Rubin et al., 1993; Ferrari and Greene, 1994). In 
support of this hypothesis, we have reported that inhibition of PC12 cell proliferative potential by expression of a dominantnegative form of Ras or that exposure of PC12 cells and sympathetic neurons to a variety of cell cycle blockers rescues them from apoptotic death caused by loss of trophic support (Ferrari and Greene, 1994; Ferrari et al., 1995; Yan et al., 1995; Farinelli and Greene, 1996; Park et al., in press). It was reported recently that PC12 cells express a constitutively active form of NOS and that this is upregulated after NGF treatment. Moreover, evidence was presented which indicated that NGF-induced NO synthesis serves to initiate cessation of proliferation in this cell line (Peunova and Enikolopov, 1995). NO has previously been shown to be cytostatic for a variety of cell types, possibly through a mechanism involving inhibition of ribonucleotide reductase (Struehr and Nathan, 1989; Garg and Hassid, 1990; Lepoivre et al., 1990; Kwon et al., 1991). These observations led us to the initial expectation that provision of extrinsic NO would prevent neuronal cells from attempting to either traverse or reenter the cell cycle and might thereby protect them from death triggered by withdrawal of trophic support. They also raised the question of whether enhancement of NO generation might account for NGF-promoted survival.

We report here that NO generators significantly retard the death of $\mathrm{PC} 12$ cells and sympathetic neurons after withdrawal of serum and/or NGF. However, our findings suggest that the mechanism of this effect is not dependent on inhibition of cellular proliferation, but rather on the activation of guanylate cyclase and generation of intracellular cGMP. Finally, our observations indicate that promotion of survival by NGF does not require generation of $\mathrm{NO}$.

\section{MATERIALS AND METHODS}

PC12 cell culture. PC12 cell cultures (passage 26-34) were maintained as described previously (Greene and Tischler, 1976; Greene et al., 1991) in RPMI 1640 medium supplemented with $10 \%$ horse scrum and $5 \%$ fetal bovine serum ( $15 \%$ serum, complete medium) and seeded on collagencoated plastic cell culture dishes (Falcon, Becton Dickinson, Lincoln Park, NJ). For the studies involving neuronally differentiated PC12 cells, naive cells were washed free of serum by three cycles of centrifugation/ resuspension in RPMI 1640 medium. The cells were then replated onto $150 \mathrm{~mm}$ collagen-coated plastic dishes in the presence of $100 \mathrm{ng} / \mathrm{ml} \mathrm{NGF}$ and harvested for survival studies $10-14 \mathrm{~d}$ later.

Assay for PC12 cell survival in serum-free or NGF-free conditions. Cell survival was assayed as previously described (Batistatou and Greene, 1991; Rukenstein et al., 1991). Cells were washed extensively with serumfree RPMI 1640 medium ( 5 times on the dish followed by 5 cycles of centrifugation/resuspension) and replated into collagen-coated 24-well tissue culture dishes at a density of $2 \times 10^{5}$ cells/well in a volume of $1 \mathrm{ml}$. In these studies, all pharmacological agents tested for their effects on survival were added at the time of plating, because it had been experimentally determined that a pretreatment period was not necessary. For determination of cell viability, cells were lysed and intact nuclei were counted using a hemacytometer (Soto and Sonnenschein, 1985) at daily intervals. In this assay, nuclei of dead cells generally disintegrate or, if in the process of apoptosis, appear pyknotic and irregularly shaped. In contrast, nuclei of living cells are phase bright and have clearly defined limiting membranes. Cell counts were performed on triplicate wells. The data are expressed as a percentage of the cell number initially plated.

$I^{3} H J$ thymidine incorporation. Assay of thymidine incorporation was conducted as described previously (Farinelli and Greene, 1996). PC12 cells were plated in collagen-coated 24 -well plates at a density of $4 \times 10^{5}$ cells/well in RPMI 1640 serum-free medium containing $3 \mu \mathrm{M}$ insulin (Sigma, St. Louis, MO). Immediately after plating, cultures were treated with the indicated $\mathrm{NO}$ generator at various concentrations and for $18 \mathrm{hr}$ befpre exposure to a $1 \mathrm{hr}$ pulse of $\left[{ }^{3} \mathrm{H}\right]$ thymidine $(1 \mu \mathrm{Ci} / \mathrm{ml})$.

Culture and survival assay of sympathetic neurons. Primary cultures of sympathetic neurons were prepared from the dissociated superior cervical ganglia of postnatal day 2 rats (Lee et al., 1980). Cells were plated at a density of 0.5 ganglia/well in 24-well collagen-coated plastic dishes. Cultures were grown in RPMI 1640 medium containing $10 \%$ heatinactivated horse serum and $100 \mathrm{ng} / \mathrm{ml}$ mouse NGF. One day after

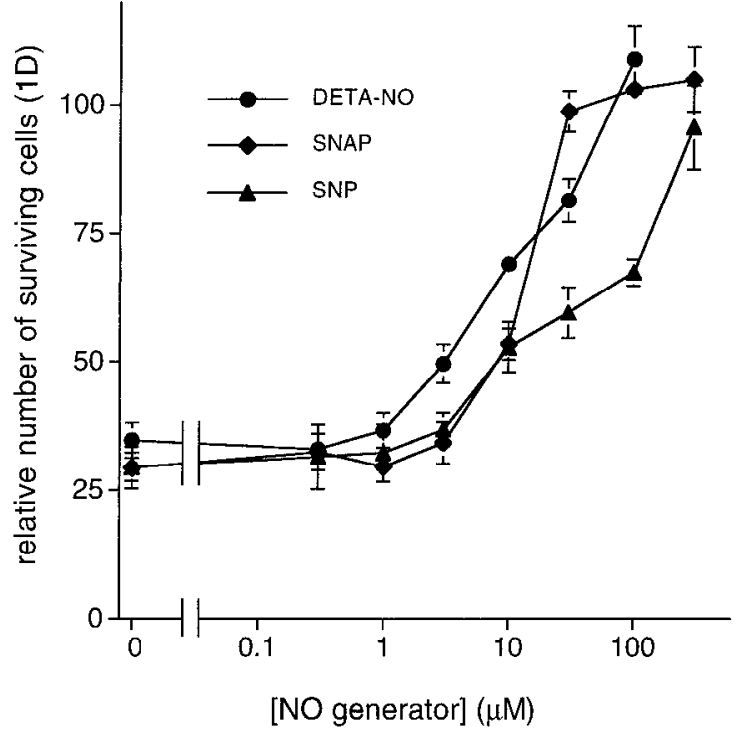

Figure 1. Dose-response relationships for the effects of NO generators on promotion of survival of PC12 cells in scrum-frec medium (1 d). NO generators prevent the death of serum-deprived PC12 cells. Cell survival data are expressed relative to the number of cells initially plated. For the survival studies, PC12 cells were not pretreated with the NO generators before serum deprivation. Data are the mean \pm SEM of three samples. In this and subsequent figures, the absence of error bars indicates that the error was smaller than the symbol used.

plating, uridine and 5-fluorodeoxyuridine (10 $\mu \mathrm{M}$ each) were added to the cultures and left for $2 \mathrm{~d}$ to eliminate non-neuronal cells. On the third day after plating, NGF was removed by washing the cultures three times witl RPMI 1640 medium containing $10 \%$ horse serum, followed by the addition of $0.5 \mathrm{ml}$ of the same medium containing antibody against mouse NGF (1:200 dilution, Sigma) and the indicated pharmacological agent(s). Toxicity of the NO generators was assessed by adding back $100 \mathrm{ng} / \mathrm{ml}$ NGF in replicate cultures after the initial NGF washout. Viability of the neurons was assessed by counting the number of intact, phase-bright neurons in each well by the method of strip counting (Greene et al., 1978; Rydel and Greene, 1988; Farinelli and Greene, 1996). This determination was made on the initial day of NGF withdrawal and then on subsequent days. Results are expressed as the percentage of viable neurons relative to that present initially after NGF withdrawal.

\section{RESULTS}

\section{NO generators suppress the death of serum-deprived PC12 cells}

To examine the effects of $\mathrm{NO}$ on neuronal cell death, we first used serum-deprived cultures of PC12 cells. In this model, typically $60-75 \%$ of the cells die after $1 \mathrm{~d}$ of serum withdrawal, and virtually all die by 3-4 d. Addition of NGF or a variety of other agents blocks this death (Rukenstein et al., 1991). As shown by the dose-response curves in Figure 1, the NO generators diethylenetriamine NO adduct (DETA-NO), $S$-nitroso- $N$ acetylpenicillamine (SNAP), and sodium nitroprusside (SNP) completely prevent the death of PC12 cells at $24 \mathrm{hr}$ after serum deprivation and do so at concentrations of $\sim 100,50$, and $300 \mu \mathrm{M}$, respectively.

We next examined the length of time that $N O$ donors were able to maintain cell viability in this paradigm. Figure $2 A$ shows that NO promotes complete survival for $1 \mathrm{~d}$ but that afterward cell viability begins to decline so that $50-80 \%$ are supported by $2 \mathrm{~d}$ and, in the cases of DETA-NO and SNP, $30-40 \%$ at $3 \mathrm{~d}$. Readdition of the NO donors at 12 or $24 \mathrm{hr}$ intervals did not prolong cell survival in the absence of trophic support (data not shown). 
A

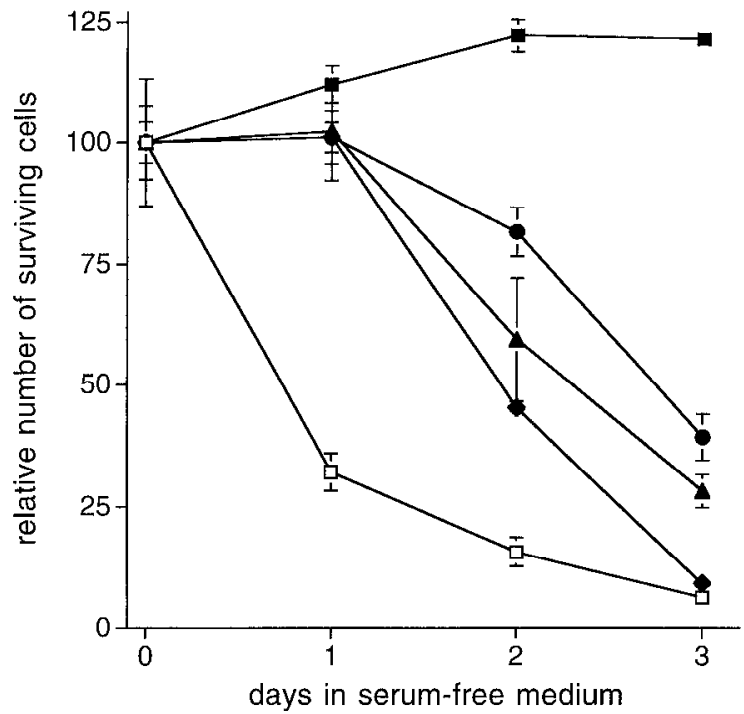

B

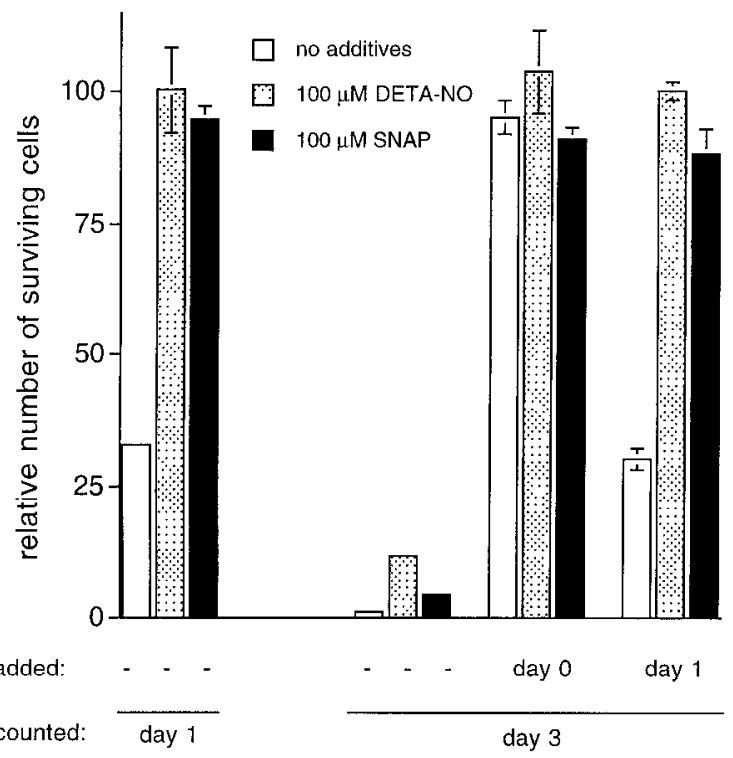

Figure 2. Time course of NO-promoted survival of PC12 cells in serumfree conditions and response of NO-treated cells to delayed addition of NGF. A, Time course. PC12 cells were washed free of serum and plated in the presence of the following: $\square$, no additives; $\square$, NGF; $\boldsymbol{0}, 100 \mu \mathrm{M}$ DETA-NO; $\downarrow, 100 \mu \mathrm{m}$ SNAP; $\boldsymbol{\wedge}, 300 \mu \mathrm{M}$ SNP. Cclls wcrc not pretrcated with the agents before serum withdrawal. No subsequent additions of the NO generators were given. $B$, Viability of NO-supported cells confirmed by NGF responsiveness. Cells were cultured for $24 \mathrm{hr}$ in serum-free medium with or without $100 \mu \mathrm{M}$ DETA-NO or $100 \mu \mathrm{M}$ SNAP, then NGF was added as indicated. Cells maintained continuously in serum-free medium containing NGF are shown for reference. Cell numbers were determined at 1 and $3 \mathrm{~d}$ after serum-deprivation times and are expressed relative to the number initially plated (day 0 ). All data are the mean \pm SEM of three samples.

Thus, in contrast to NGF, these agents block cell death for only a limited period of treatment. To confirm the viability of the cells maintained by the NO generators, cultures were prepared in serumfree medium with $100 \mu \mathrm{M}$ DETA-NO or $100 \mu \mathrm{M}$ SNAP and then 1 d later NGF was added to selected dishes. The cultures were scored for viability 1 and $3 \mathrm{~d}$ after serum deprivation. Under these conditions, the cells that had been treated for $1 \mathrm{~d}$ with DETA-NO and SNAP and then exposed to NGF were still alive at day 3 , whereas those cultures that did not receive NGF $1 \mathrm{~d}$ after serum deprivation had almost no surviving cells (Fig. $2 B$ ). These observations confirm that the cells judged to be maintained by NO generators were indeed alive and not irreversibly committed to death.

Several lines of evidence indicate that it is the NO generated by the donors that is responsible for the promotion of survival in our experiments. First, the addition of hemoglobin to the serum-free culture medium blocks the protective effects of DETA-NO, presumably by scavenging NO and preventing its action on intracellular targets. Second, in contrast to SNAP, the control thiol penicillamine, added at the same concentration does not prevent the death of serum-deprived PC12 cells (data not shown). In addition, the ability of the NO generators to promote survival is transcription-independent, because it is not blocked by addition of $10 \mu \mathrm{M}$ actinomycin D (data not shown).

\section{NO generators suppress the death of neuronal PC12 cells and primary sympathetic neurons after removal of NGF}

We next tested whether NO generators affect the death of PC12 cells that were neuronally differentiated by long-term treatment with NGF in serum-free medium, and then deprived of the factor. Serum-deprived neuronal PC12 cells, like sympathetic neurons, die after NGF withdrawal, with $\sim 50-60 \%$ of the cells dead after $2 \mathrm{~d}$. Addition of $100 \mu \mathrm{M}$ DETA-NO or $100 \mu \mathrm{M}$ SNAP to cultures of neuronal PC12 cells after withdrawal of NGF resulted in near complctc survival for up to $2 \mathrm{~d}$, and $60-75 \%$ survival at $3 \mathrm{~d}$. In contrast, only $30 \%$ of untreated cells remained viable at the latter time (Fig. 3A). The gradual decrease in the number of cells maintained by the drugs was not attributable to toxic effects because the cells remain fully viable when NGF was present in combination (data not shown). In the absence of NGF, the NO generators do not promote neurite regeneration, nor do they prevent this process in the presence of NGF (data not shown).

To extend our observations to a neuronal model, we examined the effects of the NO generators on NGF-deprived sympathetic neurons. In this paradigm, sympathetic neurons from 2 -d-old rats were cultured in the presence of NGF for $3 \mathrm{~d}$ and then deprived of the factor. Under these conditions, $\sim 75 \%$ of the neurons die within $48 \mathrm{hr}$ and virtually all die by $4-5 \mathrm{~d}$. Addition of DETA-NO or SNAP to cultures of sympathetic neurons immediately after NGF withdrawal significantly delayed their death (Fig. $3 B$ ). After $2 \mathrm{~d}$ of deprivation, $-65-75 \%$ of the NO gencrator-treated neurons were viable compared with $<35 \%$ of their untreated counterparts. Enhanced survival was still evident at $4 \mathrm{~d}$ of deprivation with $25 \%$ of the neurons still present. Readdition of the NO generators did not prolong survival nor did the presence of the generators interfere with the ability of NGF to prevent death. Figure 8 shows that the neurons rescued by the NO generators retain a typical phase bright appearance and that there is a degree of maintenance of their neurite network.

\section{Discordance between the capacities of NO generators to block cell death and cell proliferation}

Previous studies have shown that G1/S blockers rescue PC12 cells and sympathetic neurons as well as other cell types from death. Given the ability of NO-generating compounds to block PC12 cell proliferation (Peunova and Enikolopov, 1995), we tested whether this might correlate with their ability to protect neuronal cells from apoptotic death after the loss of trophic support. Each of the three NO generators inhibited $\left[{ }^{3} \mathrm{H}\right]$ thymidine incorporation by dividing PC12 cells in a concentration-dependent manner (Fig. 4). The $\mathrm{IC}_{50}$ values for DETA-NO, SNAP, and SNP are $\sim 125,45$, 

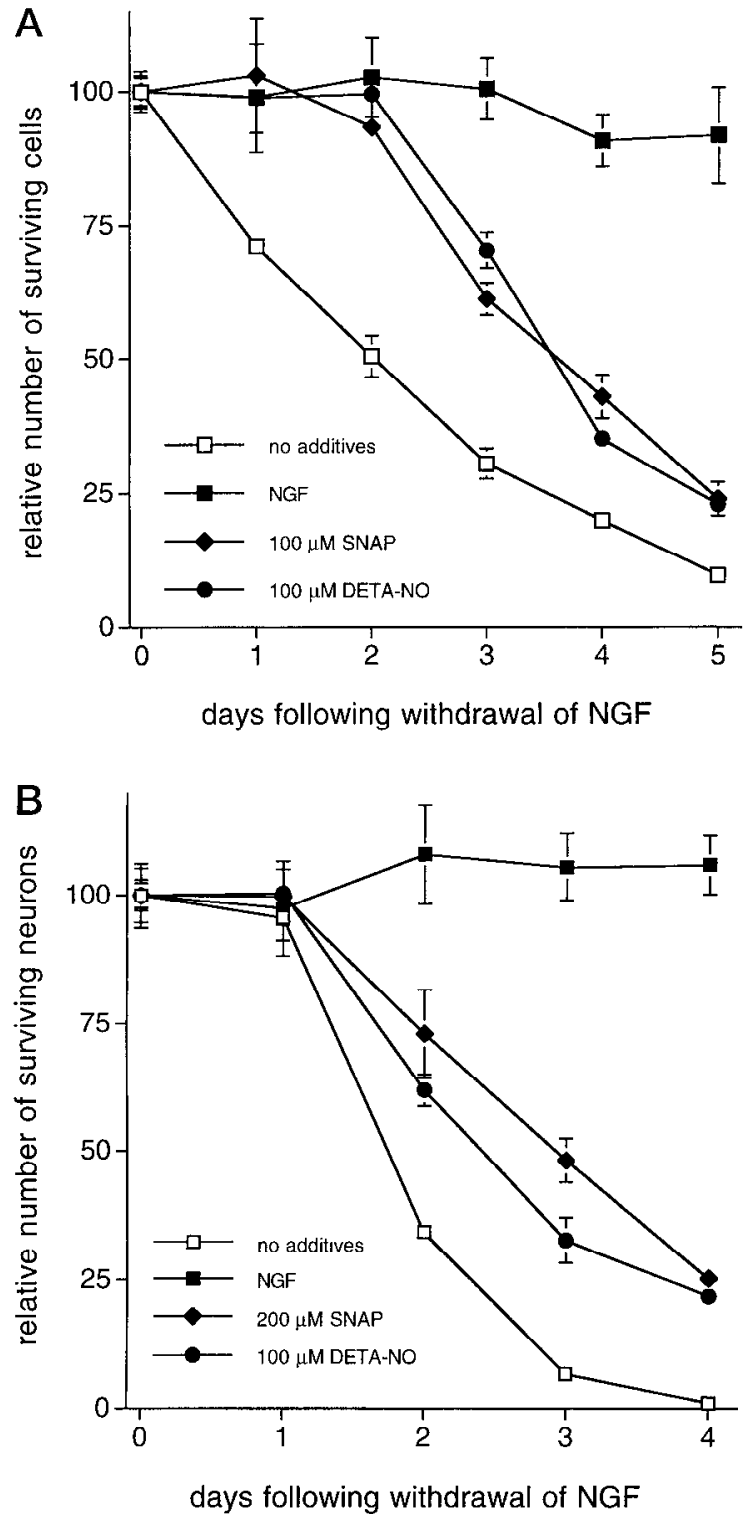

Figure 3. NO generators delay the death of neuronal PC12 cells and primary sympathetic neurons after removal of NGF. $A$, Neuronally differentiated PC12 cells. PC12 cells were neuronally differentiated by treatment with NGF for 10-14 d in serum-free medium, washed free of NGF, and replated in the presence of the indicated agent. Cultures were not pretreated with agents before NGF withdrawal. $\square$, no additives; $\mathbf{\square}$, NGF; ๑, $100 \mu \mathrm{M}$ DETA-NO; , $100 \mu \mathrm{M}$ SNAP. $B$, Effects of NO generators on survival of sympathetic neurons after removal of NGF. Neurons were cultured in the presence of NGF for $3 \mathrm{~d}$ before its withdrawal. Cultures were not pretreated with NO generators before NGF withdrawal. $\square$, no additives; $\square$, NGF; , $100 \mathrm{~mm}$ DETA-NO; $\bullet 200 \mu \mathrm{M}$ SNAP. Cell survival data are expressed relative to the number initially plated or, in the case of sympathetic neurons, present at the time of NGF withdrawal. All data are the mean \pm SEM of three samples.

and $400 \mu \mathrm{M}$, respectively. The drugs were equally effective in blocking proliferation in complete, serum-containing medium and in serum-free medium containing insulin or NGF. Comparison of the curves in Figs. 1 and 4 reveals that the concentration dependence for inhibition of DNA synthesis and for promotion of serum-free survival of PC12 cells do not strictly correlate in that inhibition of proliferation requires higher concentrations of the NO generators. For instance, DETA-NO, SNAP, and SNP pro-



Figure 4. Dose-response relationships for the cffects of NO generators on inhibition of $\left[{ }^{3} \mathrm{H}\right]$ thymidine incorporation. NO generators inhibit DNA synthesis in dividing PC12 cells. Assay of $\left[{ }^{3} \mathrm{H}\right]$ thymidine incorporation was conducted after a $19 \mathrm{hr}$ pretreatment with the indicated NO generator. Thymidine incorporation data are expressed relative to untreated control cultures. Data are the mean $\pm \mathrm{SEM}$ of three samples.

vided complete protection from death at 100,50 , and $300 \mu \mathrm{M}$ respectively, whereas at these same concentrations thymidine incorporation was blocked by only $-50 \%$. This finding contrasts with our own previous studies that showed a tight quantitative correlation between the abilities of G1/S inhibitors to block cell cycle progression and to promote survival of PC12 cells in serumfree conditions (Farinelli and Greene, 1996). These data suggest that the ability of NO to promote serum-free survival is unlikely to bc related to its cytostatic cffects. Also, in contrast to G1/S blockers, pretreatment with the NO generators before serum deprivation was not necessary to promote complete $\mathrm{PC} 12$ cell survival at $24 \mathrm{hr}$. Additionally, the cytostatic effects of the NO donors on proliferating PC12 cells did not diminish even after $4 \mathrm{~d}$, again consistent with a disjunction between promotion of survival and inhibition of proliferation (data not shown).

Inhibition of guanylate cyclase blocks the ability of NO to promote survival of PC12 cells and primary sympathetic neurons after withdrawal of trophic support

Because elevation of intracellular cGMP is one major mechanism by which effects of NO are mediated, we examined whether inhibition of guanylate cyclase would affect NO-mediated survival. The compound LY 83583 has been shown to inhibit soluble guanylate cyclase (Mulsch et al., 1988) and to block the NOmediated increase in intracellular cGMP in a variety of cell types (Laychock et al., 1991), and has been shown to inhibit NOmediated actions in PC12 cells (Desole et al., 1993). When $0.5 \mu \mathrm{M}$ LY 83583 was added to serum-deprived PC12 cell cultures concurrent with addition of the NO donors DFTA-NO, SNAP, or SNP, the survival-promoting effect of the agents was blocked (Fig. 5A). In this paradigm LY 83583 does not block the action of NGF on serum-free survival. Similar results were obtained with 10 $\mu \mathrm{M}$ methylene blue, another inhibitor of guanylate cyclase (Gruetter et al., 1981) (data not shown).

LY 83583 also blocked the ability of SNAP to promote survival 

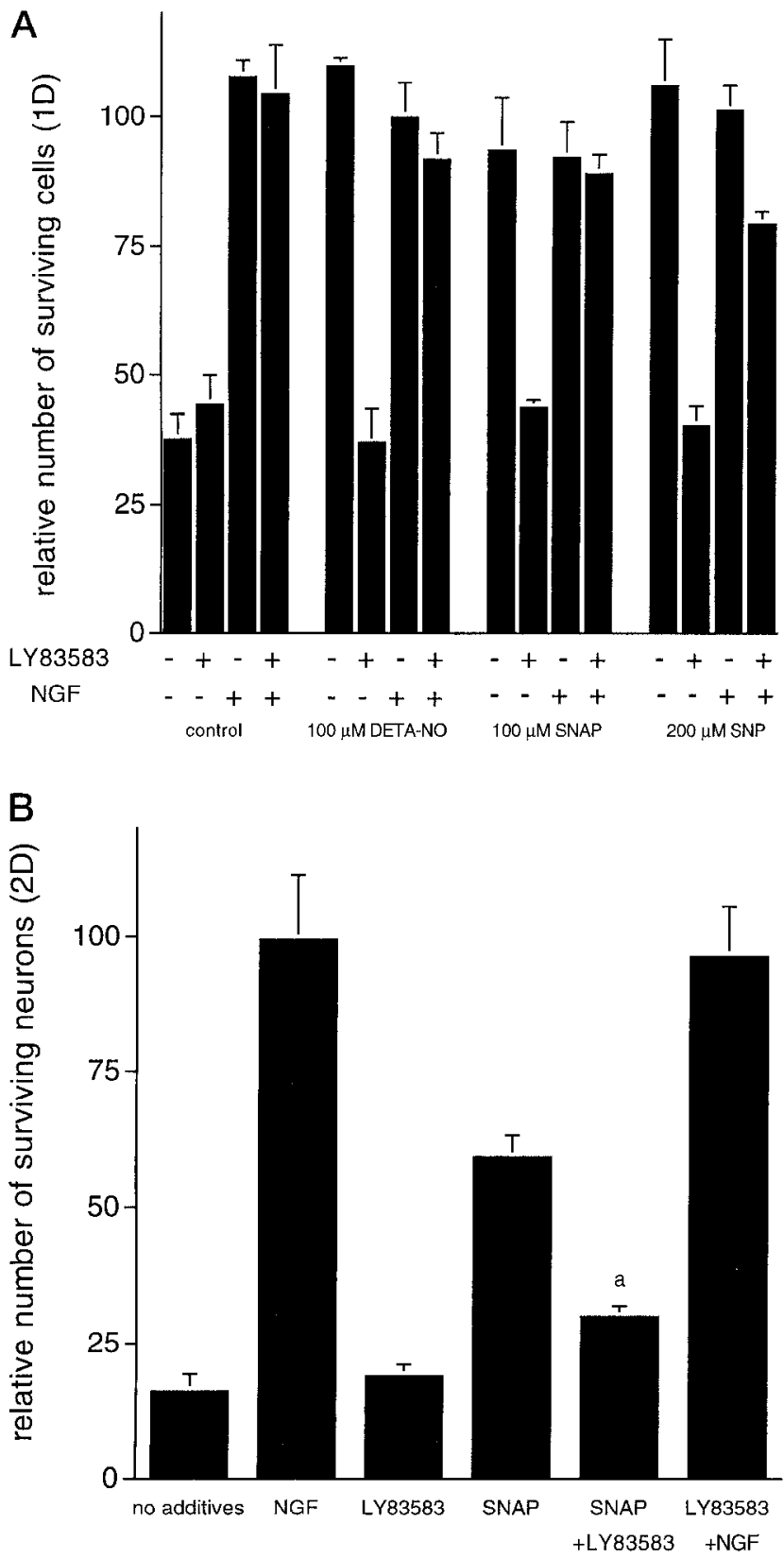

Figure 5. Inhibition of guanylate cyclase blocks the ability of NO to promote survival of PC12 cells and primary sympathetic neurons after withdrawal of trophic support. $A$, Survival of $\mathrm{PC} 12$ cells $1 \mathrm{~d}$ after removal of serum. $\mathrm{PC} 12$ cells were washed free of serum and plated in the presence of the indicated NO generator with or without $0.5 \mu \mathrm{M}$ LY 83583 (a guanylate cyclase inhibitor) and with or without NGF. Cells were not pretreated with the agents before serum withdrawal. $B$, Effects of LY 83583 on SNAP $(300 \mu \mathrm{M})$ promoted survival of sympathetic neurons $2 \mathrm{~d}$ after removal of NGF. Neurons were cultured in the presence of NGF for $3 \mathrm{~d}$ before its withdrawal. Cultures were not pretreated with NO generators or $0.25 \mu \mathrm{M} L Y 83583$ before NGF withdrawal. All data are the mean \pm SEM of three samples. $a$, Significantly less than SNAP-treated cultures $(p<0.05)$.

of primary sympathetic neurons that had been deprived of NGF. LY 83583 had no effects on survival in the absence of NGF nor did it block the ability of NGF to maintain survival (Fig. $5 B$ ). These data suggest that the survival promoting effects of NO are mediated through activation of guanylate cyclase. In contrast, it appears that the action of NGF in promotion of survival is not mediated by cGMP.

\section{Inhibition of cGMP-specific phosphodiesterase} enhances the survival effects of the NO donors

To test further whether cGMP mediates the neuroprotective effect of NO, we examined the consequences on cell survival of blocking cGMP phosphodiesterase. Dipyridamole is a relatively selective inhibitor of c(iMP-specific phosphodiesterase (Beavo and Reifsnyder, 1990). We first tested dipyridamole for its effects on serum-deprived PC12 cells. When administered alone, $10 \mu \mathrm{M}$ dipyridamole has a negligible effect on survival in this paradigm. However, when added in combination with the NO generators DETA-NO, SNAP, or SNP, dipyridamole causes a consistent shift in the potency of these agents by about threefold (Fig. $6 A-C$ ). Dipyridamole also prolongs the time that the NO generators support survival of serum-deprived PC12 cells so that with the drug, there was complete survival for $2 \mathrm{~d}$ after serum withdrawal (Fig. 6D). However, by the third day there was no significant difference in viability between cells treated with the NO generators plus dipyridamole and those cells treated with the generators alone, although survival in both groups was significantly greater than the untreated control cultures (data not shown). Inhibition of cGMP phosphodiesterase with $100 \mu \mathrm{m}$ Zaprinast similarly enhanced the survival-promoting effects of the NO donors on serum-deprived PC12 cells (data not shown).

Dipyridamole also prolonged the survival of sympathetic neurons deprived of NGF and maintained with the NO generator SNAP. Addition of $10 \mu \mathrm{M}$ dipyridamole alone had negligible effects on survival in this paradigm, but cxtended the length of survival of the SNAP-treated cultures by $\sim 1 \mathrm{~d}$ compared with SNAP alone (Fig. 6E).

\section{Permeant cGMP analogs promote survival of trophic factor-deprived PC12 cells and primary sympathetic neurons}

We next tested whether cGMP had direct effects on neuronal cell survival by adding the permeant cGMP analogs 8-bromo-cGMP (8-Br-cGMP) or chlorphenylthio-cGMP (CPT-cGMP) to cultures of serum-deprived $\mathrm{PC} 12$ cells. Both analogs promote serum-free survival in a concentration-dependent manner (Fig. 7A). CPTcGMP prevents cell death completely at a concentration of $1 \mathrm{~mm}$ $\left(\mathrm{EC}_{50} \sim 0.3 \mathrm{mM}\right)$, whereas 8 -Br-cGMP completely protects at 10 $\mathrm{mM}\left(\mathrm{EC}_{50} \sim 3 \mathrm{mM}\right)$. Five days after removal of serum, $60 \%$ of PC12 cells were still maintained by $10 \mathrm{~mm}$ 8-Br-cGMP, whereas none of the untreated control cells survived. In contrast, addition of $10 \mathrm{~mm}$ 8-bromoguanosine $5^{\prime}$-monophosphate had no effect on survival of serum-deprived PC12 cells; therefore, survival appears unlikely to be attributable to a nonspecific action of the nucleotide derivative. It is also unlikely that the cGMP analogs promote survival by blocking cell proliferation, because treatment of dividing PC12 cells with $10 \mathrm{~mm} 8$-Br-cGMP resulted in only a $30 \%$ inhibition of $\left[{ }^{3} \mathrm{H}\right]$ thymidine incorporation compared with untreated control cultures.

Addition of the permeant cGMP analogs to cultures of sympathetic neurons immediately after NGF withdrawal rescued them from death (Fig. $7 B$ ). After $2 \mathrm{~d}$ of deprivation, $\sim 90 \%$ of the 8-Br-cGMP-treated neurons and 70\% of the CPT-cGMP-treated neurons were alive compared with $<20 \%$ of their untreated counterparts. 8-Br-cGMP had good long-term effects on survival as $\sim 50 \%$ of the neurons remained viable $7 \mathrm{~d}$ after removal of NGF whereas CPT-cGMP had shorter-lived effects on survival. Such cultures treated with these analogs maintained their neurite network in the absence of NGF in contrast to the dying, untreated controls (Fig. 8). 

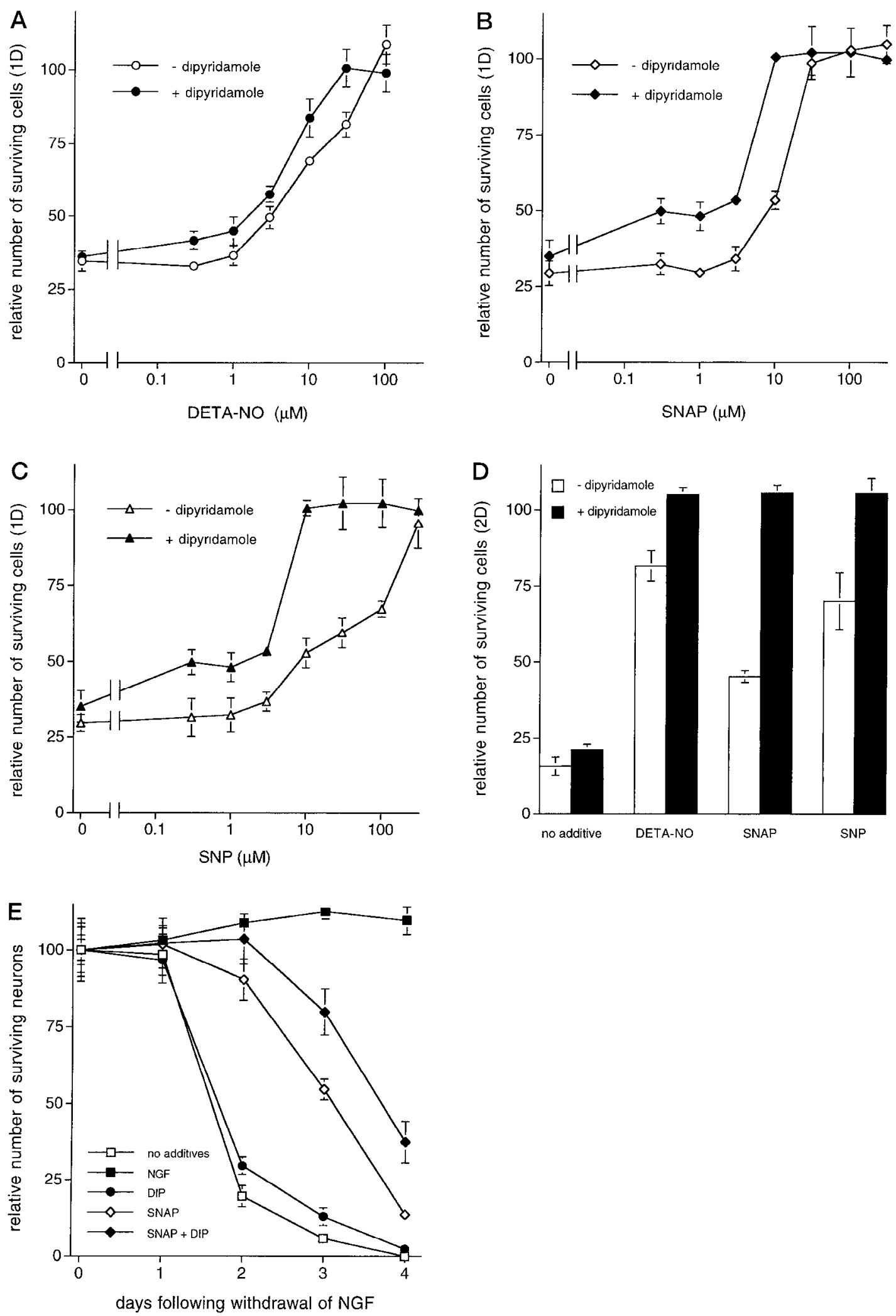

Figure 6. Inhibition of cGMP-specific phosphodiesterase enhances the survival-promoting action of the NO generators on serum-deprived PC12 cells and NGF-deprived sympathetic neurons. $A-C$, Dipyridamole shifts the dose-response curve for the effect of NO donors on PC12 cell survival. PC12 cells were washed free of serum and plated in the presence of the indicated NO generator with or without $10 \mu \mathrm{M}$ dipyridamole. Cells were not pretreated with the agents before serum withdrawal. $D$, Dipyridamole prolongs survival-promoting action of the NO generators on PC12 cell survival. Data represent survival $2 \mathrm{~d}$ after removal of serum. $E$, Dipyridamole prolongs survival-promoting action of an NO generator on NGF-deprived sympathetic neurons. Neurons were cultured in the presence of NGF for $3 \mathrm{~d}$ before its withdrawal. Cultures were not pretreated with the NO generator before NGF withdrawal. $\square$, no additives; $\square$, NGF; $\bullet 10 \mu \mathrm{M}$ dipyridamole; $\diamond, 100 \mu \mathrm{M}$ SNAP; $\bullet, 100 \mu \mathrm{M}$ SNAP $+10 \mu \mathrm{m}$ dipyridamole. All data are the mean \pm SEM of three samples. 

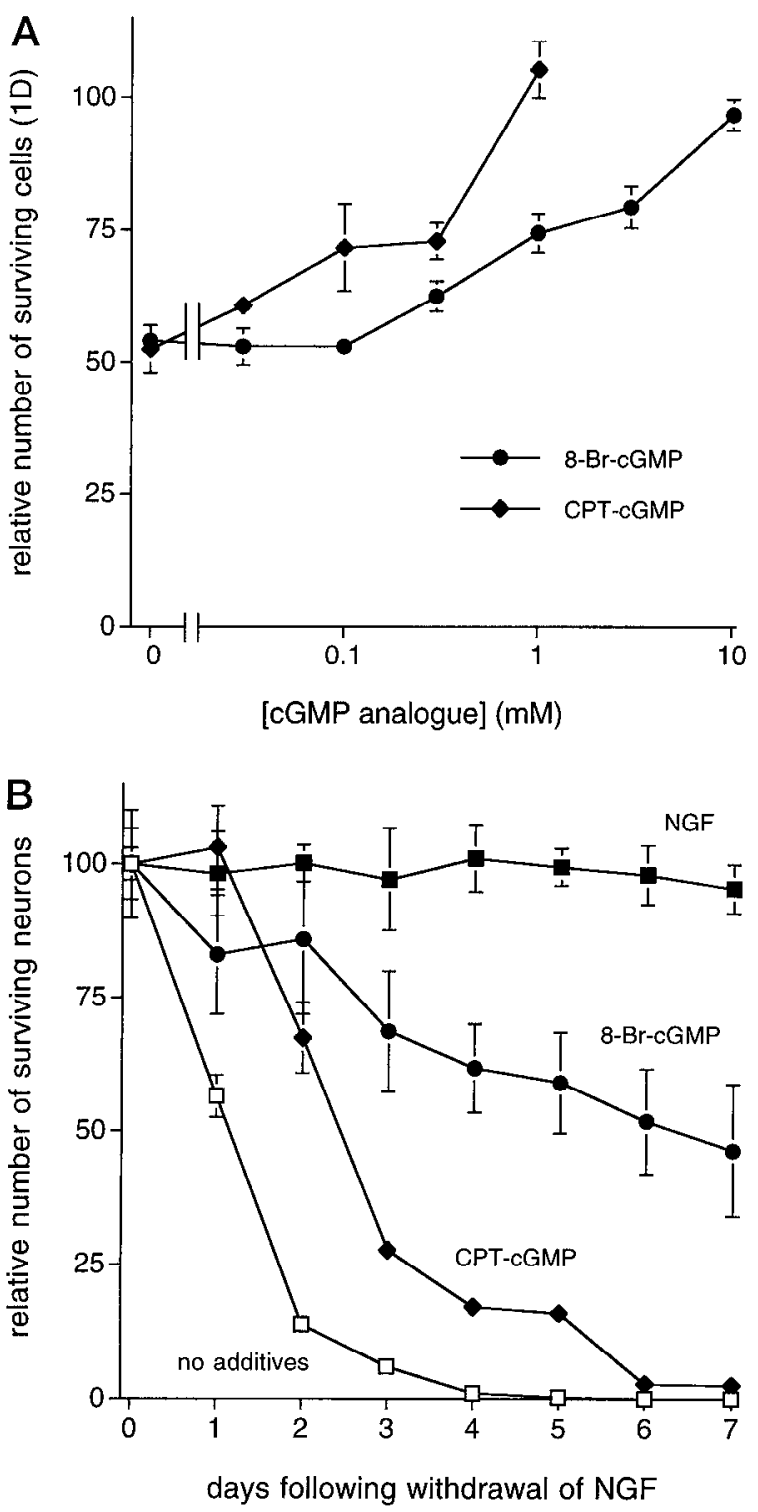

Figure 7. Permeant cGMP analogs promote survival of trophic factordeprived PC12 cells and primary sympathetic neurons. $A$, Dose-response relationships for promotion of survival of PC12 cells in serum-free medium ( $1 \mathrm{~d}$ ) by cGMP analogs. PC12 cells were not pretreated with the analogs before serum deprivation. Cell survival data are expressed relative to the number initially plated. $B$, Effects of permeant cGMP analogs on survival of sympathetic neurons after removal of NGF. Neurons were cultured in the presence of NGF for $3 \mathrm{~d}$ before its withdrawal. Cultures were not pretreated with cGMP analogs before NGF withdrawal. $\square$, no additives; $\boldsymbol{\square}$, NGF; $\bullet, 1 \mathrm{mM}$ CPT-cGMP; $10 \mathrm{~mm}$ 8-Br-cGMP. All data are the mcan \pm SEM of threc samples.

\section{The NOS inhibitor $\boldsymbol{N}$-nitro-L-arginine methyl ester (L-NAME) does not block NGF-promoted survival of serum-deprived PC12 cells}

NGF has been reported to induce NO synthase in PC12 cells and the induction of NOS and subsequent generation of NO has been calsally linked to the cessation of proliferation and neuronal differentiation initiated by NGF (Peunova and Enikolopov, 1995). We tested whether inhibition of NOS would prevent the NGF-promoted survival of serum-deprived PC12 cells. When added immediately after serum withdrawal at concentrations up to $20 \mathrm{~mm}$, the NOS inhibitor L-NAME failed to block NGF-promoted survival of PC12 cells (data not shown). Even after $5 \mathrm{~d}$ in the presence of high concentrations of L-NAME, NGF maintained complete survival of PC12 cells, indicating that the action of NGF on survival is not mediated by NO. L-NAME by itself had no effect on survival in this paradigm. In addition, L-NAME $(10 \mathrm{~mm})$ did not block NGF-promoted survival of neuronal PC12 cells in serum-free medium or of primary sympathetic neurons (data not shown).

\section{DISCUSSION}

In the present study we show that neuronal cell death initiated by withdrawal of trophic support can be significantly delayed by NO generators. Our findings suggest that the survival-promoting effect of NO is mediated by elevation of intracellular cGMP, implicating either or both of these messenger molecules as regulators of survival or apoptosis. Furthcrmorc, our data indicatc that the mechanism by which NGF promotes neuronal survival is unlikely to involve the production of $\mathrm{NO}$ or activation of soluble guanylate cyclase.

We and others have hypothesized that trophic factors such as NGF promote survival either by guiding proliferating neuroblasts through the cell cycle, by causing dividing neuroblasts to differentiate and withdraw from the cell cycle, or by causing postmitotic neurons to renlain out of the cycle (Brooks et al., 1993; Rubin et al., 1993; Ferrari and Greene, 1994; Ferrari et al., 1995; Farinelli and Greene, 1996). We have provided support for this model by showing that blockade of the cell cycle by molecular or pharmacological means is sufficient to prevent death of $\mathrm{PC} 12$ cells and sympathetic neurons after withdrawal of trophic support (Ferrari and Greene, 1994; Ferrari et al., 1995; Yan et al., 1995; Farinelli and Greene, 1996; Park et al., in press). Because it has been demonstrated that NGF treatment of PC12 cells leads to induction of a constitutively active form of NOS and that the production or application of NO initiates cessation of proliferation by these cells (Peunova and Enikolopov, 1995), it was reasonable to test whether the cytoprotective effects of NO were causally related to inhibition of cellular proliferation. When NO generators were tested for their ability to promote PC12 cell survival in serum-free conditions and to inhibit PC12 DNA synthesis, it became evident that the dose-response curves for these two processes did not strictly correlate (Figs. 1, 4). This discordance is not evident with $N$-acetylcysteine (Ferrari et al., 1995), G1/S blockers and permeant cAMP analogs (Farinelli and Greene, 1996), and inhibitors of cyclin dependent kinases (Park et al., in press), in that each blocked cell death and DNA synthesis with similar potencies.

Because inhibition of cell proliferation was not sufficient to explain the cytoprotective effects of NO, we looked toward one of the main targets of its action, guanylate cyclase. Past studies have demonstrated that NO generators elevate cGMP levels in PC12 cells (Whalin et al., 1991). Inhibition of guanylate cyclase with LY 83583 and methylene blue was sufficient to block the protective actions of the NO generators in our models. In addition, it was possible to enhance and prolong the effects of NO generators by cotreating with the cGMP phosphodiesterase inhibitor dipyridamole. These data together with the cytoprotection afforded by the permeant cGMP analogs strongly suggest that the effect of NO on survival in our paradigm is mediated by activation of guanylate cyclase and generation of cGMP. Our findings are consistent with those demonstrating that cGMP mediates the effect of NO in preventing B-cell death (Genaro et al., 1995), and in preventing the death of cytokine-deprived eosinophils (Beauvais et al., 1995). In addition, a study by Weill and Greene (1984) showed that naturally occurring death of chick motor neurons could be prevented by dibutyryl cGMP. Moreover, Barger et al. (1995) demonstrated that secreted forms of the $\beta$-amyloid precursor protein 

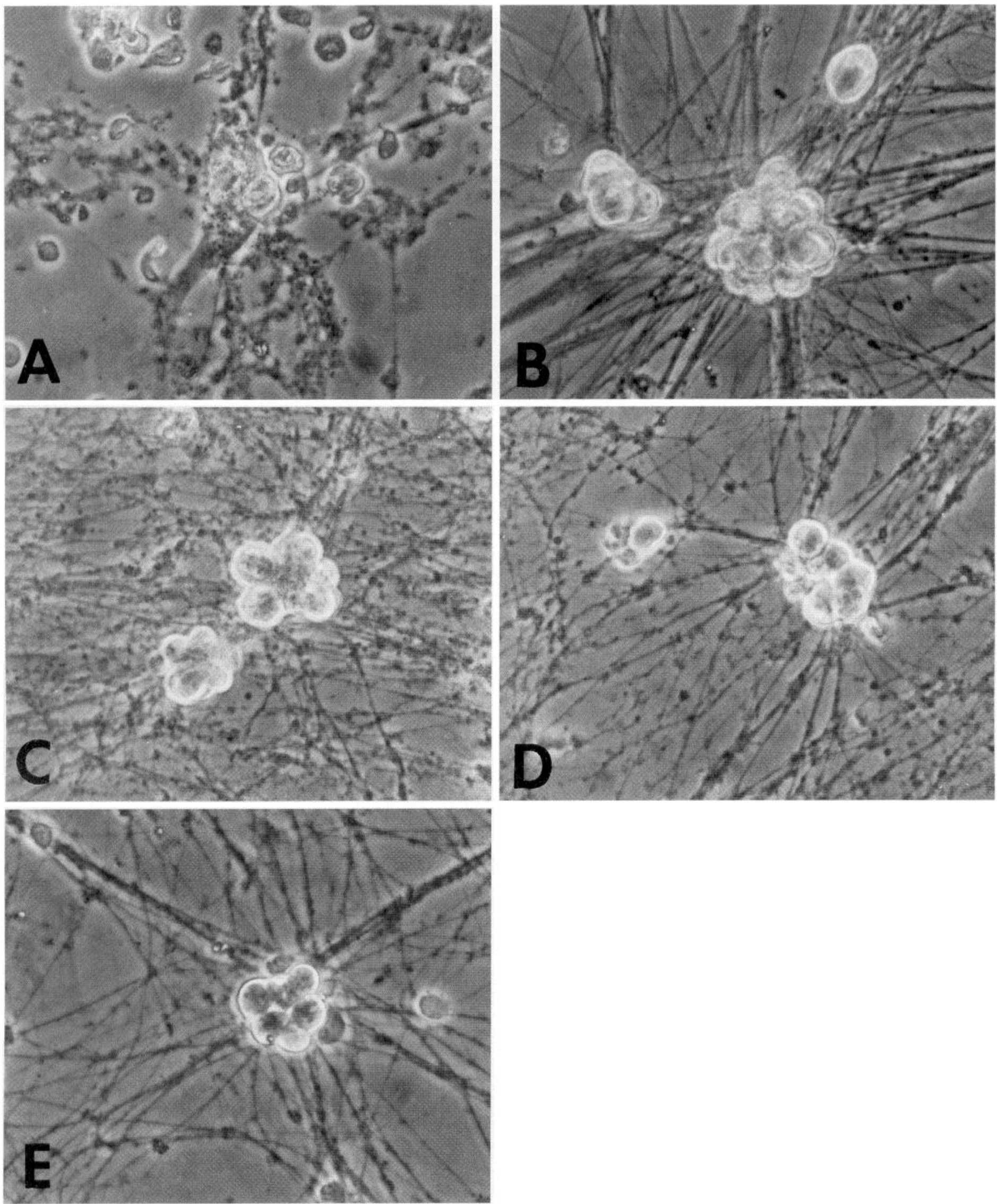

Figure 8. Phase-contrast micrographs of cultured primary sympathetic neurons maintained for $3 \mathrm{~d}$ after withdrawal of NGF and addition of $(A)$ no additives, $(B) 100 \mathrm{ng} / \mathrm{ml}$ NGF, $(C) 100 \mu \mathrm{M}$ DETA-NO, $(D) 300 \mu \mathrm{M}$ SNAP, and $(E) 10 \mathrm{~mm}$ 8-Br-cGMP. Magnification, $375 \times$. 
protected cultured hippocampal neurons against glucose deprivation and glutamate toxicity by increasing cGMP levels. Taken together, these data strongly suggest that cGMP may be a regulator of neuronal survival.

Our effects of NO on neuronal survival are short-lived and cannol be prolonged by readdition of NO generators, suggesting that the protective response is somehow downregulated. The observations that inhibition of cGMP phosphodiesterase prolongs the protective action of $\mathrm{NO}$ and that 8 -Br-cGMP maintains survival longer than does $\mathrm{NO}$ indicate that the downregulation occurs at the level of guanylate cyclase. This idea is supported by studies of the circulatory system that show that guanylate cyclase is sensitive to the continued presence of NO in that this enzyme can be upregulated by removal of NO (Moncada et al., 1991) and downregulated by extended exposure to NO donors (Axelsson and Andersson, 1983; Waldman et al., 1986)

One of the known targets of cGMP action is the cyclic nucleotide phosphodiesterase family, which, depending on the isoform, can be either stimulated or inhibited by the cyclic nucleotide (Sonnenburg and Beavo, 1994). This raises the possibility that NO may indirectly affect the intracellular level of cAMP through cGMP-mediated inhibition of phosphodiesterase. A related possibility was that cGMP derivatives we used might similarly raise intracellular cAMP or even mimic the action of the latter. Previous studies have demonstrated that elevation of intracellular cAMP or addition of a permeant CAMP analog result in long-term maintenance of survival after trophic factor withdrawal from $\mathrm{PC} 12$ cells and sympathetic neurons (Rydel and Greene, 1988; Rukenstein et al., 1991). However, we have observed a close quantitative correlation between the ability of a cAMP analog to block PC12 cell proliferation and to prevent cell death (Farinelli and Greene, 1996). In contrast, 8-Br-cGMP inhibits $\left[{ }^{3} \mathrm{H}\right]$ thymidine incorporation by just $30 \%$ at $10 \mathrm{~mm}$, the concentration required to completely block cell death in our experiments. A similar absence of correlation between survival and DNA synthesis was observed with NO generators. Moreover, Whalin et al. (1991) reported that elevation of cGMP in PC12 cells activates phosphodiesterase II and that this in turn increases the rate of cAMP degradation in the cells. Thus, present observations do not favor the likelihood that NO or cGMP promote survival by a cAMPdependent mechanism.

Downregulation of copper/zinc superoxide dismutase (SOD1) in PC12 cells using an antisense oligonucleotide leads to their rapid apoptotic death (Troy and Shelanski, 1994). In this model, NO generators expedite cell death while inhibitors of NOS abolish cell death, suggesting that formation of peroxynitrite is necessary for this process (Troy et al., 1996). In the models of trophic factor deprivation-induced death presented here, NO generators promote survival and inhibition of NOS has no effect. It is conceivable that NO becomes cytotoxic only under conditions of increased superoxide. Because NO has been reported to be a potential mediator of NMDA neurotoxicity after ischemia (Nowicki et al., 1991; Dawson et al., 1993), it appears likely that the oxidative state of the target cell can determine whether NO is cytoprotective or cytotoxic.

It has been known for some time that SOD prolongs the effect of exogenous NO, presumahly hy reducing the level of superoxide (Moncada et al., 1986; Ignarro et al., 1987) and thus diminishing its reaction with NO to form peroxynitrite. It has also been reported that SOD itself is capable of catalyzing the reversible conversion of nitroxyl anion to NO, a reaction that would serve to prolong the action of NO (Murphy and Sies, 1991). With regard to the finding by Greenlund et al. (1995), who reported that micro- injection of copper/zinc SOD or SOD expression vector delayed the death of sympathetic neurons deprived of NGF, it is conceivable that this treatment results in an increase in intracellular levels of NO by the mechanisms mentioned above, and consequently leads to cGMP accumulation and prolonged survival.

In summary, we have shown that NO may play a role in promoting neuronal survival. In our models of trophic factor withdrawal, this effect appears to be mediated by cGMP. Our findings thus predict that signals in addition to NO that result in elevation or maintenance of intracellular cGMP may contribute to cell survival. In this light, it is of interest that natriuretic peptides increase cGMP in neuronal cells (Toki et al., 1992) and that guanylate cyclase can be activated by protein kinase C (Louis et al., 1993), activators of which can block apoptosis in both neuronal and non-neuronal cells (Rajotte et al., 1992; Batistatou and Greene, 1993; Lucas et al., 1994, 1995). Carbon monoxide, which is produced physiologically by the action of heme oxygenase, also activates guanylate cyclase, and interestingly these two enzymes colocalize in the brain (Verma et al., 1993). It is thus conceivable that in addition to conventional trophic factors, NO and other signaling molecules that elevate intracellular cGMP may serve to prevent neuronal apoptosis in development as well as in the mature organism. It also follows that manipulation of intracellular cGMP represents a potentially useful means to prevent death of neurons and other cells caused by disease or injury.

\section{REFERENCES}

Axelsson KL, Andersson RGG (1983) Tolerance towards nitroglycerin, induced in vivo, is correlated to a reduced cGMP response and an alteration in cGMP turnover. Eur J Pharmacol 88:71-79.

Barger SW, Fiscus RR, Ruth P, Hofmann F, Mattson MP (1995) Role of cyclic GMP in the regulation of neuronal calcium and survival by secreted forms of beta-amyloid precursor. J Neurochem 64:2087-2096.

Batistatou A, Greenc LA (1991) Aurintricarboxylic acid rescues PC12 cells and sympathetic neurons from cell death caused by nerve growth factor deprivation: correlation with suppression of endonuclease activity. J Cell Biol 115:461-471.

Batistatou A, Greene LA (1993) Internucleosomal DNA cleavage and neuronal cell survival/death. J Cell Biol 122:523-532.

Beauvais F, Michel L, Dubertret L (1995) The nitric oxide donors, azide and hydroxylamine, inhibit the programmed cell death of cytokinedeprived human eosinophils. FEBS Lett 361:229-232.

Beavo JA, Reifsnyder DH (1990) Primary sequence of cyclic nucleotide phosphodiesterase isozymes and the design of selective inhibitors. Trends Pharmacol Sci 11:150-155.

Beckman JS, Beckman TW, Chen J, Marshall PA, Freeman BA (1990) Apparent hydroxyl radical production by peroxynitrite: implications for cndothelial injury from nitric oxide and superoxide. Proc Natl Acad Sci USA 87:1620-1624.

Bredt DS, Snyder SH (1992) Nitric oxide, a novel neuronal messenger Neuron 8:3-11.

Brooks SF, Gibson LA, Rubin LL (1993) Apoptosis induced by NGFwithdrawal from differentiated $\mathrm{PC} 12$ cells involves activation of $\mathrm{P} 34^{\text {tali2 }}$ kinase. Soc Neurosci Abstr 1:885.

Dawson VL, Dawson TM, London ED, Bredt DS, Snyder SH (1991) Nitric oxide mediates glutamate neurotoxicity in primary cortical cultures. Proc Natl Acad Sci USA 88:6368-6371.

Dawson VL, Dawson TM, Bartley DA, Uhl GR, Snyder SH (1993) Mechanisms of nitric oxide-mediated ncurotoxicity in primary brain cultures. J Neurosci 13:2651-2661.

Desole MS, Kim WK, Rabin RA, Laychock SG (1991) Nitric oxide reduces depolarization-induced calcium influx in $\mathrm{PC} 12$ cells by a cyclic GMP-mediated mechanism. Neuropharmacology 33:193-198.

Edwards SN, Buckmaster AE, Tolkovsky AM (1991) The dealh programme in cultured sympathetic neurones can be suppressed at the post-translational level by nerve growth factor, cyclic AMP and depolarization. J Neurochem 57:2140-2143.

Estevez AG, Radi R, Barbeito L, Shin JT, Thompson JA, Beckman JS (1995) Peroxynitrite-induced cytotoxicity in PC12 cells: evidence for an apoptotic mechanism differentially modulated by neurotrophic factors. J Neurochem 65:1543-1550. 
Farinelli SE, Greene LA (1996) The cell cycle blockers mimosine, ciclopirox and deferoxamine prevent the death of PC12 cells and postmitotic sympathetic neurons following removal of trophic support. J Neurosci 16:1150-1162.

Ferrari G, Greene LA (1994) Proliferative inhibition by dominantnegative Ras rescues naive and neuronally-differentiated PC12 cells from apoptotic death. EMBO J 13:5922-5928.

Ferrari G, Yan CYI, Greene LA (1995) $N$-Acetylcysteine (D- and L-stereoisomers) prevents apoptotic death of neuronal cells. J Neurosci $15: 2857-2866$

Garg UC, Hassid A (1990) Nitric oxide-generating vasodilators inhibit mitogenesis and proliferation of $B A L B / c$ C $3 T 3$ fibroblasts by a cyclic GMP-independent mechanism. Biochem Biophys Res Commun 171:474-479.

Garthwaite J (1991) Glutamate, nitric oxide and cell cell signalling in the nervous system. Trends Neurosci 14:60-67.

Genaro AM, Hortelano S, Alvarez A, Martinez-A C, Bosca L (1995) Splenic B lymphocyle programmed cell death is prevented by nitric oxide release through mechanisms involving sustained $\mathrm{Bcl}-2$ levels. $\mathrm{J}$ Clin Invest 95:1884-1890.

Greene LA (1978) Nerve growth factor prevents the death and stimulates neuronal differentiation of clonal $\mathrm{PC} 12$ pheochromocytoma cells in serum-free medium. $\mathrm{J}$ Cell Biol 78:747-755.

Greenlund LJS, Deckwerth TL, Johnson Jr EM (1995) Superoxide dismutase delays neuronal apoptosis: a role for reactive oxygen species in programmed neuronal death. Neuron 14:303-315.

Gruetter CA, Gruetter DY, Lyon JE, Kadowitz PJ, Ignarro LJ (1981) Relationship between cyclic guanosine $3^{\prime}, 5^{\prime}$-monophosphate formation and relaxation of coronary arterial smooth muscle by glyceral trinitrate, nitroprusside, nitrate and nitric oxide: effects of methylene blue and methemoglobin. J Pharmacol Exp Ther 219:181-186.

Ignarro LJ, Buga GM, Wood KS, Byrns RE, Chaudhuri G (1987) Endothelium-derived relaxing factor produced and released from artery and vein is nitric oxide. Proc Natl Acad Sci USA 84:9265-9269.

Johnson III G, T'sao PS, Lefer AM (1991) Cardioprotective effects of authentic nitric oxide in myocardial ischemia with reperfusion. Crit Care Med 19:244-252.

Kwon NS, Stuehr DJ, Nathan CF (1991) Inhibition of tumor cell ribonucleotide reductase by macrophage-derived nitric oxide. J Exp Med 174:761-767.

Laychock SG, Modica ME, Cavanaugh CT (1991) L-Arginine stimulates cyclic guanosine $3^{\prime}, 5^{\prime}$-monophosphate formation in rat islets of Langerhans and RINm5F insulinoma cells: evidence for L-argininc:nitric oxide synthase. Endocrinology 129:3043-3052.

Lee VM, Shelanski ML, Greene LA (1980) Characterization of antisera raised against cultured rat sympathetic neurons. Neuroscience $5: 2239-2245$

Lepoivre M, Chenais B, Yapo A, Lemaire G, Thelanders L, Tenu J (1990) Alterations of ribonucleotide reductase activity following induction of the nitrite-generating pathway in adenocarcinoma cells. J Biol Chem 265:14143-14149.

Lipton SA, Choi Y, Pan Z, Lei SZ, Chen HV, Sucher NJ, Loscalzo J, Single DJ, Stamler JS (1993) A redox-based mechanism for the neuroprotective and neurodestructive effects of nitric oxide and related nitroso-compounds. Nature 364:636-632.

Lomo J, Blomhoff HK, Beiske K, Stokke T, Smeland EB (1995) TGF-b1 and cyclic AMP promotc apoptosis in resting human B lymphocytcs. J Immunol 154:1634-1643.

Louis J, Revel M, Zwiller J (1993) Activation of solublc guanylate cyclase through phosphorylation by protein kinase $\mathrm{C}$ in intact PC12 cells. Biochim Biophys Acta 1177:299-306.

Lucas M, Sanchez-Margalet V, Sanz A, Solano F (1994) Protein kinase C activation promotes cell survival in mature lymphocytes prone to apoptosis. Biochem Pharmacol 47:667-672.

Mannick JB, Asano K, Izumi K, Kieff E, Stamler JS (1994) Nitric oxide produced by human B lymphocytes inhibits apoptosis and Epstein-Barr virus reactivation. Cell 79:1137-1146.

Mitrovic B, Ignarro LJ, Vinters HV, Akers M-A, Schmid I, Uittenbogaarts C, Merrill JE (1995) Nitric oxide induces necrotic but not apoptotic cell death in oligodendrocytes. Neuroscience 65:531-539.

Moncada S, Palmer RMJ, Gryglewski RJ (1986) Mcchanism of action of some inhibitors of endothelium-derived relaxing factor. Proc Natl Acad Sci USA 83:9164-9168.

Moncada S, Rees DD, Schulz R, Palmer RMJ (1991) Development and mechanism of a specific supersensitivity to nitrovasodilators after inhi- bition of vascular nitric oxide synthesis in vivo. Proc Natl Acad Sci USA $88: 2166-2170$

Morikawa E, Huang Z, Moskowitz MA (1992) L-Arginine decreases infarct size caused by middle cerebral arterial occlusion in SHR. Am J Physiol 263:H1632-H1635.

Mulsch A, Busse R, Liebau S, Forstermann U (1988) LY 83583 interferes with the release of endothelium-derived relaxing factor and inhibits soluble guanylate cyclase. J Pharmacol Exp Ther 247:283-288.

Murphy ME, Sies H (1991) Reversible conversion of nitroxyl anion to nitric oxide by superoxide dismutase. Proc Natl Acad Sci USA 88:10860-10864.

Nowicki JP, Duval D, Poignet H, Scatton B (1991) Nitric oxide mediates neuronal death after focal cerebral ischemia in the mouse. Eur J Pharmacol 204:339-340.

Park DS, Farinelli SE, Greenc LA (1996) Inhibitors of cyclin-dependent kinases promote survival of post-mitotic neuronally differentiated PC12 cells and sympathetic neurons. $J$ Biol Chem, in press.

Peunova N, Enikolopov G (1995) Nitric oxide triggers a switch to growth arrest during differentiation of neuronal cells. Nature 375:68-73.

Rajotte D, Haddad P, Haman A, Cragoe Jr EJ, Hoang T (1992) Role of protein kinase $\mathrm{C}$ and the $\mathrm{Na}^{+} / \mathrm{H}^{+}$antiporter in suppression of apoptosis by granulocyte macrophage colony-stimulating factor and interleukin-3. J Biol Chem 267:9980-9987.

Rubin LL, Philpott KL, Brooks SF (1993) The cell cycle and cell death Curr Biol 3:391-394.

Rukenstein A, Rydel RE, Greene LA (1991) Multiple agents rescue $\mathrm{PCl} 2$ cells from serum-free cell death by translation- and transcriptionindependent mechanisms. J Neurosci 11:2552-2563.

Rydel RE, Grecne LA (1988) cAMP analogs promote survival and neurite outgrowth in cultures of rat sympathetic and sensory neurons independently of nerve growth factor. Proc Natl Acad Sci USA 85:1257-1261.

Siegfried MR, Erhardt J, Rider T, Ma X, Lefer AM (1991) Cardioprotection and attenuation of endothelial dysfunction by organic nitric oxide donors in myocardial ischemia-reperfusion. J Pharmacol Exp Ther 260:668-675.

Snyder SH (1992) Nitric oxide: first in a new class of neurotransmitters? Science 257:494-496.

Sonnenburg WK, Beavo JA (1994) Cyclic GMP and regulation of cyclic nucleotide hydrolysis. Adv Pharmacol 26:87-114.

Soto AM, Sonnenschein C (1985) The role of estrogens on the proliferation of human breast tumor cells (MCF-7). J Steroid Biochem 23:87-94.

Stamler JS (1994) Redox signaling: nitrosylation and related target interactions of nitric oxide. Cell 78:931-936.

Stuchr DJ, Nathan CF (1989) Nitric oxide: a macrophage product responsible for cytostasis and respiratory inhibition in tumor target cells. J Exp Med 169:1543-1555.

Toki S, Morishita Y, Sano T, Matsuda Y (1992) HS-142-1, a novel non-peptide ANP antagonist, blocks the cyclic GMP production elicited by natriuretic peptides in PC12 and NG108-15 cells. Neurosci Lett 135:117-120.

Troy CM, Shelanski ML (1994) Down-regulation of copper/zinc superoxide dismutase causes apoptotic death in PC12 neuronal cells. Proc Natl Acad Sci USA 91:6384-6387.

Troy CM, Derossi D, Prochiantz A, Greene LA, Shelanski ML (1996) Downregulation of SOD1 leads to cell death by the NO-peroxynitrite pathway. J Neurosci 16:253-261.

Verma A, Hirsch DJ, Glatt CE, Ronnett GV, Snyder SH (1993) Carbon monoxide: a putative neural messenger. Science 259:381-384.

Waldman SA, Rapoport RM, Ginsburg R, Murad F (1986) Desensitization to nitroglycerin in vascular smooth muscle from rat and human. Biochem Pharmacol 35:3525-3531.

Weill CL, Greene DP (1984) Prevention of natural motoneurone cell death by dibutyryl cyclic GMP. Nature 308:452-454.

Whalin ME, Scammell JG, Strada SJ, Thompson WJ (1991) Phosphodiesterase II, the cGMP-activatable cyclic nucleotide phosphodiesterase, regulates cyclic AMP metabolism in PC12 cells. Mol Pharmacol 39:711-717.

Yan CYI, Ferrari G, Greene LA (1995) N-Acetylcysteine-promoted survival of PC12 cells is glutathione-independent but transcriptiondependent. J Biol Chem 270:26827-26832.

Zhang J, Dawson VL, Dawson TM, Snyder SH (1994) Nitric oxide activation of poly(ADP-ribose) synthetase in neurotoxicity. Science 263: $687-689$. 